\title{
Convergence and Divergence: A Christian Response to Prozesky's 'Global Ethic' and Secular Spirituality
}

\author{
Louise Kretzschmar \\ Kretzl@unisa.ac.za
}

\begin{abstract}
The aim of this article is to identify areas of convergence and divergence in the value systems of secular ethics and Christian ethics and to address what is meant by the moral development of individual persons and communities. The article discusses the views of Martin Prozesky on religion, the creation of a global ethic and secular spirituality from the perspective of Christian ethics. The discussion draws on the 'Barthian-Thomism' of Nigel Biggar and the four key moral questions posed by Dallas Willard in order to identify elements of convergence and divergence related to worldviews, values, virtues and the moral development of persons and groups.
\end{abstract}

Keywords: value systems, secular ethics, Christian ethics, moral development, global ethics, secular spirituality, worldviews, values, virtues

\section{Introduction}

A massive poster that currently adorns a wall of the University of South Africa (Unisa) reads, 'Education is the great engine of personal development' (Nelson Mandela). It is a shortened version of a statement in The Long Walk to Freedom: The Autobiography of Nelson Mandela (1994: 144):

Education is the great engine of personal development. It is through education that the daughter of a peasant can become a doctor; that the 
son of a mineworker can become the head of the mine; that the child of farm workers can become the President of a great nation.

Few would question the truth of this statement, but what is 'education'? A narrow understanding of education includes the accumulation of knowledge and skills for example, in the fields of medicine, the social sciences, business, and law.

However, were moral education to be omitted from the social educational endeavours of families, schools, civil society and the universities, society would be exposed to doctors, mine-owners and presidents who could abuse their positions and power' ${ }^{1}$ Thus Prozesky (2014: 297) notes that '... there can be no evading of responsibility for ethical enhancement by our universities ...'. Venter (2012: 111-118) argues that theologians at public universities must examine the ethical dimension of knowledge construction and that moral virtue needs to be part of communal life and social well-being.

This article forms part of a festschrift that seeks to honour the work of Professor Prozesky, and is written in a context of moral complexity and crisis in South Africa ${ }^{2}$. In recent years, many reports have emerged in South Africa about instances of fraud, corruption, the abuse of power and a disregard for the humanity and rights of others on the part of leaders within the government. These include the reports of the highly regarded former Public Protector, Thuli Madonsela, Secure in comfort and State Capture (Gqubule 2017: 85-179) and Jacques Pauw's exposé published in 2017, The President's Keepers: Those Keeping Zuma in Power and out of Prison. On the other hand, some in government, business and civil society have acted in ways that are fair, honest and socially responsible ${ }^{3}$.

1 Recent South African examples include those implicated in the Life Esidemini and Aurora mine scandals and the Presidency of Jacob Zuma.

${ }^{2}$ During February 2018, South Africans witnessed the resignation of President J. Zuma and the inauguration of Matamela Cyril Ramaphosa as their new president. Ramaphosa's government now has the massive task of eliminating corruption, dealing with contentious issues such as land redistribution and rebuilding the country. Yet, many of those officials complicit in the dereliction of their duties during the previous administration remain in their posts.

${ }^{3}$ For instance, see T.M.G. Digital, Politics: Vytjie Mentor endorses Mcebisi Jonas over proclamation on Guptas (2016). 
The aim of this article is to note these contradictory moral realities, identify areas of convergence and divergence in the value systems of secular and Christian ethics (Prozesky 2013: 8) and to address the nature and means of the moral development of individual persons and communities. Hence, the article discusses the views of Prozesky on religion, the creation of a global ethic and secular spirituality, along with the views of some secular humanists, from the perspective of Christian ethics.

The methodology employed is to draw on the Barthian-Thomism of Nigel Biggar ${ }^{4}$ and four key moral questions posed by Dallas Willard ${ }^{5}$ to identify the convergence and divergence between secular and Christian perspectives on reality, values and moral development. The article draws on the disciplines of Theological Ethics and Applied Ethics. Theological Ethics or, (in this instance), Christian Ethics is an important perspective because in many of his works, Prozesky discusses religion, especially the Christian faith, alongside a variety of ethical concerns related to public affairs. Biggar (2011:45) states that,

... Christians should look to the integrity of their ethics - to its theological narrative integrity $-\ldots$ [and] they should expect to find consensus with non-Christians on ethical matters - but only occasionally and provisionally.

In this article, the discipline of Christian Ethics is not seen as a minor subspecies of Ethics, relevant only to Christians. Rather, the article compares the writings of thinkers (Christians and others) who all contribute to the common task of defining the nature of ethics, based on the presuppositions and perceptions of reality that influence their interpretation of the data they draw from the human, natural, economic and other sciences.

This discussion of secular and Christian ethics is relevant to the teaching and practice of Applied Ethics because it seeks to identify, evaluate and apply ethical understanding and moral teaching to specific contexts and

${ }^{4}$ Biggar is Professor of Moral and Pastoral Theology at the University of Oxford and Director of the McDonald Centre for Theology, Ethics and Public Life.

${ }^{5}$ Willard (1935 - 2013) was a Professor of Philosophy at the University of Southern California and a well-known Christian author and public speaker. 
problems within social experience (see Beauchamp, Walters, Kahn \& Mastroianni 2014; Rossouw \& Van Vuuren 2010). For this reason there has been a resurgence of interest in the teaching of virtue ethics in university courses or degrees and in the ethical issues of business, medicine, the Church, the environment, the law and politics (Kretzschmar \& Bentley 2013). In addition, the websites of organisations such as the Ethics Institute of South Africa (2018) and the Business Ethics Network of Africa (BEN-Africa, 2018) advertise conferences, seminars and training in the area of applied business ethics.

\section{The Work of Professor Martin Prozesky}

Professor Prozesky's long and distinguished career commenced at the University of Rhodes in 1969 where he was a temporary lecturer. Later he was a Professor Emeritus and Senior Research Associate at the University of KwaZulu Natal (UKZN). Most of his academic life was spent at UKZN, but he was also a visiting scholar at universities such as Oxford, California, Sydney, Cape Town and the Free State. He published books and articles in various fields of research, including Religious Studies (1984; 1996), Theology (1990; 1992) and Ethics (2007) ${ }^{6}$. He also contributed to debates on current affairs in local newspapers. Prozesky was a founder member of the academic journal Religion in Southern Africa (renamed the Journal for the Study of Religion), and of the Unilever Ethics Centre in Pietermaritzburg. In this article, particular attention is paid to his writings on secular spirituality, a 'global ethic' and moral formation.

Initially, I only knew Professor Prozesky by repute. Later I met him at academic conferences. In an earlier article (Kretzschmar 2008), I interacted with Professor Prozesky's writings on secular spirituality and revised a chapter in the book Ethics for accountants and auditors (Kretzschmar 2012). I am grateful for this opportunity to engage further with the thinking of Professor Prozesky. I deeply value his integrity, collegiality, dedication to the search for truth, openness and commitment to social justice. Nevertheless, much as I agree with certain of his convictions, in some respects my own views differ from his as I argue below.

${ }^{6}$ Other articles in this journal issue discuss several additional elements of Professor Prozesky's writings. 


\section{Nigel Biggar's Barthain-Thomism}

In his book, Behaving in Public: How to do Christian Ethics (2011), Biggar argues for a via media that he calls 'Barthian-Thomism'. Biggar refuses to choose between "conservative" biblical and theological seriousness [and] "liberal" engagement with social policy' (Biggar 2011: xvii).

Biggar (2011: 26-29) draws on Aquinas's notion of natural law (Summa Theologica Ia IIae.94.2), and argues that Christians need to recognise that moral wisdom can be found outside the Church and that Christians can engage with other thinkers about the nature of reality and pertinent ethical issues based on our common humanity. The world, because it is God-created, bears the imprint of God's design and ordering. By using our God-given reasoning powers, human beings can acquire some understanding of the world. While it is true that human understanding is damaged by sin, Biggar (2011: 29) says,

... for Aquinas, human reason unaided by special revelation is still capable of grasping accurately some important ethical things, as is implied by his own heavy borrowing from the ethical thought of the pre-Christian Aristotle.

Christian and secular thinkers can find a meeting point in their experience of life, and they can reflect on the meaning of life, human nature and the universe in which we live. For Christians, or other religious believers, to insist that one can only talk to those who share one's faith is to end the conversation before it has begun.

Biggar (2011: 19-20, 83-7, 109-110) notes the theologian Barth's openness to learning from those outside the Church. However, Biggar (2011: $7-9,110)$ points out that from Barth we also learn that without God's revelation we cannot arrive at a full and proper understanding of the nature of reality or moral matters because sin has marred and distorted human reason. Hence, Christians who engage in a dialogue with other thinkers need to maintain their 'theological integrity', and contribute their insights on creation, human nature, Christology, salvation, eschatology and the like to the wider discourse because these are essential to their convictions about reality and morality.

Such a Barthian-Thomist dialogue opens up and enlivens a debate about both convergence and divergence between secular and Christian think- 
ers. In such a dialogue, the parties need to commit themselves to consider the arguments and not resort to misrepresenting or denigrating each other's positions. Biggar (2011: 7,75) argues against disrespect and humiliation in favour of engagement, communication and persuasion, but with a willingness to listen, learn, and be humble and charitable. In a public debate, what is said is as important as how it is said (Biggar 2011: 47). He goes on to say that mere tolerance is not enough because in the context of rank injustice, 'critical candour' or 'prophetic denunciation' need to be employed in the interests of truth and justice (Biggar 2011: 71-73, 108).

\section{A Dialogue in Response to Willard's Four Questions}

In pursuit of the moral debate between Christians, secular thinkers, agnostics or members of other religious faiths, Willard (2009: 50-56, 61) ${ }^{7}$ poses the following four questions:

1. What is reality? (The worldview issue)

2. Who is well off or blessed? (What is well-being or the good life?)

3. Who is a truly good person? (The issue of moral character)

4. How does one become a truly good person? (The development issue)

In the next section, I compare the views of Prozesky and other thinkers on these questions.

\section{What is Reality? (The Worldview Issue)}

In a chapter entitled 'Ethics, spirituality and the secular', Prozesky (2006: 128) states, 'In short, nothing less than a fully inclusive global ethic is now urgently in need of creation by people with truth and goodness in their heart, minds and efforts'. Prozesky (2006: 129-30) goes on to propose a secular ethic and is highly critical of religion. He writes:

${ }^{7}$ I pose similar questions in Kretzschmar (2012: 61-68): 'Why should anything be Valued; What is a good life; Why should I be moral; and What is the role of moral communities?

${ }^{8}$ Their writings do not respond directly to Willard's questions, but I have sought to select those that deal with these aspects of the moral debate. 
Religion as we usually encounter it cannot provide a shared basis for the transforming, enriching and sustainable ethical praxis in the world, and probably never will. Furthermore, I am increasingly persuaded that religion as we know it can no longer even provide a home for spirituality.

He argues that religion is 'a game of power, control and domination', it 'divides people and cultures' and inculcates 'spiritual dependency and passivity' (Prozesky 2006: 131). He continues:

Nor can anyone who has experienced religion from within be unaware that its priorities are not concern for the greatest well-being of this wounded world of ours. Its gaze is fixed on heaven, not earth (Prozesky 2006: 131).

In the place of religion, Prozesky proposes the creation of a secular spirituality and a global ethic, '... ethics cannot avoid an engagement with spirituality if it is to be holistically transforming and enriching' (Prozesky 2006: 129). Yet, in developing his secular spirituality and global ethic, Prozesky draws on the sacred writings of leaders within these self-same despised religions. For example, he refers to Moses, Jesus, Muhammad, the Buddha, Confucius, African sages and Gandhi (Prozesky 2006: 131). This raises further questions: which criteria should be used to select 'the best' elements of these religions; how should they be arrived at; and, are they valid? I return to this point below.

It is certainly true that particular religious teachings and practices need to be criticised. A religion that turns its back on the 'woundedness' of the world can be criticised as faulty or distorted ${ }^{9}$. Furthermore, to defend actions that are clearly immoral, such as religious persecution, violence and abusive practices, is both wrong and unwise. Similarly, to create a caricature of religion, one that draws only on negative examples is also not valid. With reference to Christianity, further distinctions can be made. Consider for example the difference between the civil religion exemplified by the many individuals who loosely identify themselves as 'Christians' and genuine, practicing believers,

${ }^{9}$ Hence, Henri Nouwen (1979) speaks of Christ (and Christian believers) as 'wounded healers'. 
or between authentic and abusive religious teachings and practices. As G. K. Chesterton stated, 'Christianity has not so much been tried and found wanting, as it has been found difficult and left untried' (quoted in Willard 1988: $1)^{10}$.

Particular religious abuses cannot invalidate the teachings of all religions and the ethical practices of their adherents. In the same way that the actions of some corrupt doctors, engineers or lawyers do not totally invalidate medicine, engineering or the law, so the abuse of religion cannot invalidate all faith traditions. Arguably, Prozesky recognises the validity of this argument, as he draws on the 'best' examples of religious moral values in his construction of a global ethic. Furthermore, religious traditions such as Christianity do subject themselves to internal critique. Thus in Judaism, prophets such as Isaiah and Amos denounced religious ritual that was hypocritical because social justice was disregarded and, in the New Testament, Jesus and the apostles spoke out vehemently against behaviour that was immoral and unjust.

It is important to note the difference between Prozesky's secular spirituality and the 'new' atheism of Dawkins, Harris and Hitchens. He draws the following distinction (2009: 242) between the terms 'secular' and 'secularism':

'Secular' means independent of religious control of any kind; it means fairness and neutrality of stance towards them, but the neutrality is an enabling or facilitative neutrality because it provides freedom of belief and operation for all. By contrast, 'secularism' is a philosophy or ideology which opposes religion, deeming it to be a bad thing, at best confused and at worst deeply damaging to humanity.

Though critical of religion, Prozesky draws on certain religious values and examples in the construction of his global ethic. However, it is questionable whether his critique of religion as outlined above fully displays the fairness and neutrality spoken of here. It appears that Prozesky's global ethic is an essentially secular one, albeit one that draws on particular religious traditions,

${ }^{10}$ See Part I, Chapter 5, 'The Unfinished Temple' (no pagination) of Chesterton's book, What's Wrong with the World, https://www.basilica.ca/ documents/2016/10/G.K.Chesterton-Whats\%20Wrong\%20With\%20The\% 20World.pdf. (Accessed on 27 February 2018). 
as a commitment to a particular faith tradition is not required nor is a belief in God.

Secular humanists and atheists (Markham 2007: 80-88) go much further than Prozesky and stress the purely material nature of the universe and also reject any notion of the existence of a personal, creator God who is transcendent Spirit. Christians are accused of holding views that are antiquated and contrary to reason. Yet, secular thinkers may assume that their own views are beyond reproach. However, can a secular and materialist understanding of reality provide an explanation for the origin of the universe, and why anything ought to be valued?

The following question is posed by Haught - if reality is conceived of as being purely material, from where do secular thinkers derive the notion that human reason ought to be valued, that human beings have dignity and rights, and that morality is important (Haught 2008: 15-27)? Haught further states,

Dawkins and his associates [the new atheists] declare that reference to God is unreasonable, but what is really unreasonable is their refusal to look for an ultimate explanation as to why the universe is intelligible, why truth is worth seeking, and why we can trust our minds as they reach toward deeper understanding and truth (Haught 2008: 52).

Interestingly, Anthony Flew, well known for his earlier atheist position and critiques of the 'proofs' for the existence of God, later on moved to a deist position because of the scientific evidence for design provided by 50 years of DNA research. According to Young (2010: 1), Flew came to recognise that '... by the almost unbelievable complexity of the arrangements which are needed to produce [life], that intelligence must have been involved'.

According to Biggar (1997: 5-6), if there is no transcendent and objective moral referent, then moral values are not real but only a matter of personal taste or human will,

... there remains no longer any hope or rational discussion about moral matters. Since there is no moral reality to know, moral opinions cannot claim to know it. They can therefore be neither true nor false. So when moral opinions clash, the conflict cannot be resolved by an appeal to reason. It can only be solved by the triumph of one will over anotherthat is, by the triumph of superior might. 
Moreover, appeals to reason, moral value, justice, personal integrity or the common good cannot sway those who do not recognise these as values, let alone as moral obligations.

By way of contrast, a Christian view of reality is that we live in an intelligible, God-shaped universe. God is the creator and designer of the physical universe and further sustains the world, counteracting the forces of entropy. God, on the one hand, is transcendent and infinitely mysterious, and on the other hand, immanent and willing to enter into relationships with human beings. Rather than a precarious trust in human reason and experience alone, a Christian ethic is based on a view of a God-shaped reality that evokes wonder, overcomes evil and enjoins believers to embark on a rigorous process of moral conversion. God is the objective referent of the morality partly perceived by human beings and the source of a deeply imbedded moral conscience which itself needs to be redeemed and cultivated. Through Christ's incarnation, suffering and victory over evil and death, God provides a pathway for our human redemption and restoration, and for that of a deeply damaged physical world $^{11}$.

Hence, the essential divergence between a Christian view of reality and that of Prozesky is that the former is based on God as a transcendent, yet knowable, Being and it draws on both natural law and revelation. The latter view of reality is a secular spirituality based on human experience and reason, together with some religious insights.

\section{Who is Well off or Blessed? (What is Well-being or the Good Life?)}

Willard's second question asks how can the 'good' life, or a life worth living, be characterised. Prozesky (2013: 8-10) stresses the 'convergence', or widespread acceptance of core moral values, between adherents of different religions and other moral thinkers:

It can be summarized as the twin core values of a willingness to com-

${ }^{11}$ Space does not permit a discussion of the 'problem of evil' or the 'problem of goodness'; the former presents a challenge to theists and the latter a challenge to atheists. 
bine legitimate self-interest with real, active concern for others, coupled with integrity, understood as consistently honest behaviour.

Elsewhere, Prozesky (in Rossouw, Prozesky, Burger, du Plessis \& van Zyl 2007:44) quotes the American secular humanist philosopher, Paul Kurtz ${ }^{12}$ who argues that humanity ought to progress beyond religious faith to a 'higher' stage of ethical existence. He provides this four-point statement of the 'common moral decencies' that reveal how good people should live (Kurtz 1988: 82-96):

- Integrity, which includes truthfulness, promise-keeping, sincerity and honesty;

- Trustworthiness, which involves fidelity or faithfulness, and dependability;

- Benevolence, which includes goodwill, non-malfeasance as applied to persons and property, sexual consent and beneficence;

- Fairness, including gratitude, accountability, justice, tolerance and cooperation.

Prozesky also draws on the writings of Rushworth M. Kidder (1994: 18) who lists the following eight core values shared across cultures: love, truthfulness, fairness, freedom, unity, tolerance, responsibility and respect for life.

The values suggested by Prozesky, Kurtz and Kidder can be endorsed by Christians. Arguably, these values are secular versions of long-standing Judeo-Christian norms and values. For example, the Judeo-Christian norm, 'be holy as I am holy' is replaced by 'integrity'; faith in God and living in accordance with God's moral will are replaced by 'trustworthiness'; 'love your neighbour' is replaced by 'benevolence'; and acting justly because one is a recipient of God's grace, forgiveness and love is replaced by 'fairness'. Nevertheless, a significant degree of convergence exists between secular and Christian ethics about what can be considered to be the moral values that are recognised as essential to a good life.

Although there may be areas of agreement because of what Aquinas called 'natural theology', secular ethics and Christian ethics are not fully

12 See Lowder (2001) for a summary of a debate between Kurtz (secular humanism) and Craig (theism). 
compatible because of the former's partial or complete dismissal of God. Further, Christian morality is about more than human flourishing; it is based on faith in God, agape (love), love for God, self, other human beings and creation, and the hope of the resurrection and the life to come (Wright 2010: 181- 89).

Hence, this discussion asks whether (as Prozesky has done in the creation of his global ethic and secular spirituality) moral values can be separated from the particular worldviews with which they are associated? Moral values such as justice and compassion may be lauded, but on which moral worldview are these based or, as Biggar (2001:1-10) partly drawing on what Hauerwas (1981 \& 1983) would say, out of which narratives do they emerge?

Although many may agree that the values already mentioned are important, why ought human beings be required to adhere to them? Are they values that we recognise as being important, or are they norms and obligations that have to be obeyed? Moral obligation, as noted above by Biggar, cannot be derived from divergent human opinions or a relativist view of morality. Thus, lacking an objective transcendent moral Being, on what basis can human beings be obliged to resist self-gratification and promote the well-being of others? According to Christian Ethics, loving one's neighbour, including one's enemies, is a clear Divine command, though difficult to obey. It extends beyond moral choice to service and, often, sacrifice. Although people holding to a variety of worldviews may themselves make sacrifices, such as doctors who work in war-torn areas of the world, on what moral basis can those who adhere to a secular ethic call upon others (or themselves) to do so?

In Christian Ethics, love is the ultimate moral value because God is love. Further, human well-being, moral understanding and the appreciative stewardship of creation are derived from a deepening relationship with God. This relationship is mystical, intimate, transforming and very practical. Wisdom and an ever-deepening understanding of God and love for one's neighbour are the result. Human conscience, albeit imperfect, is part of our human essence because we are made in the image of a good God. Even human intelligence, through which we reason, seeking to understand our world, is a gift of God. Along with material needs, the 'good life' as Christians understand it, also encompasses hope for the future, meaning and connectedness. Connection with God provides a sense of belonging and meaning within the vast universe (Küng 1997: 142-43) and moral obligations are derived from 
theological understanding. A good relationship with God and others provides both nurture and opportunities for care and creativity in the context of the family, faith community, friendships, society and the world of work.

In short, for Prosezky the good life is one that excludes selfishness and greed and has a concern for others. Christian ethicists would agree with and support this understanding. However, according to Christians, because a good life is founded on and motivated by God, it cannot be fully understood or experienced apart from God. A life lived according to the will of God, in God's gracious presence, is not simply a good, but a blessed life.

\section{Who is a Truly Good Person? (The Issue of Moral Character)}

In this section, Willard's third question is discussed, how can human goodness be understood? Prozesky (2007: 105) proposes that the following nine values provide a basis of moral goodness,

... generosity, integrity, truthfulness, respect, justice and fairness, inclusiveness, responsible effort in the service of the good, freedom governed by responsibility, and beauty of presence.

What we want, says Prozesky (2013: 18) is integrity, other-concern and honourable behaviour, and what we do not want is selfishness, greed, theft and cheating.

Christians can readily accept the importance of these values and the need for them to be exhibited in virtuous behaviour. Not only the adherents of different religious faiths, but also the critics of religion can agree that these values are central to human flourishing. Certainly, life in the family, churches, business world, medicine and government would be improved by practical adherence to these and similar values. However, it is significant that the key Christian values of faith, hope and love and the virtue of humility are absent from this list (Wright 2010: 181 - 98).

As noted by Prozesky and Biggar above, human reason and experience can produce a measure of agreement on what constitutes a good life. Nevertheless, a secular approach to ethics cannot easily explain why morality is important for human life to flourish. Is it by accident or design that a moral 
life is essential to human well-being? Those who advocate one or another form of a secular ethic also need to defend which criteria are to be used to choose one set of values over another. For instance, on what basis are humility and faith excluded from a global ethic, whereas justice and integrity are included? Because some people do not believe in God, Prozesky (2007: 121-22) employs 'inclusiveness' as a criterion and thereby excludes a distinctively Christian ethic. Is this inclusiveness a valid criterion? Complete inclusiveness is not possible as there are conflicting values, for example, group loyalty versus justice. This means that moral choices need to be made, not only between what is right and wrong, but also between one value and another.

The question is, can a purely secular ethic fully sustain and motivate moral life in a South African or any other context? Can values, once separated from the religious framework from which they are derived, especially if they contain no ultimate sense of purpose (telos) or accountability, supply the moral obligation required to overcome greed and violence? Another significant area of divergence is that secular approaches see no need for morality to be based on the human experience of God's love that motivates love for God, others and all that God has created.

\section{How Does One Become a Truly Good Person? (The Development Issue)}

Willard's final question deals with moral formation; how are integrity and other moral virtues to be developed in persons and communities?

It is noticeable that discussions of ethics based on a secular view of reality mention the need for moral values and virtues, but rarely pay attention to how virtuous character can be formed. For instance, virtue ethics and the need for virtues such as openness, integrity and benevolence are mentioned in the widely used text Business ethics (e.g. Rossouw \& van Vuuren 2006: 59-63, 148-152. The fourth edition of this book (Rossouw \& van Vuuren 2010: 6771, 124-137) also discusses virtue ethics according to Aristotle. It goes on to discuss ethics and human potential, noting the 'ethical neglect' in organisations and arguing that people's ethical potential ought to be unlocked. However, a discussion of the means of moral formation is absent and, other than noting that religious traditions are against consumerism, mentioning the role of the church in the Middle Ages and religious affiliations (2010: 26, 174, 264), 
religious faith as a means of unlocking this ethical potential is not discussed ${ }^{13}$. A further example can be seen in Baker's (2009: 23) commissioned discussion of Business Ethics. He admits that,

Producing more businessmen with this quality [a highly developed sense of ethics] is slow work since it depends upon the complex and long-term influence of family, culture, religion, education and the level of the moral democratic and economic development of a country.

He does not discuss how moral character is to be formed, but rather lamely remarks, 'Ethical rules are found in many forms, all of which hopefully can improve conduct' (Baker 2009: 10).

Prozesky (2007: 77) rightly emphasises the importance of the moral choices we make:

It is the choice whether we will live mainly for ourselves, or with real, active concern for others as well, the choice between basically selfish and unselfish ways of relating to others - between generosity and greed.

Moral choice is indeed vital, but who or what will convince those who are greedy and immoral to change their ways? Can a course in Applied Ethics, for example, address the formation of moral character and produce commitment to moral action?

According to Prozesky (2006: 137), what we need to take us towards a future with less suffering and greater well-being is, '... a new kind of soul on this planet, involving a fresh confederation of conscience, knowledge, love and spirit'. Whereas Kurtz deliberately excludes God from his moral vision, Prozesky's global ethic does not require faith in God. Elsewhere Prozesky (2007: 1) states,

Conscience - and conscience alone - can be the foundation for a greater global flourishing, but only if we make it richer, deeper and stronger

${ }^{13}$ See Kretzschmar (2012: 27-70) for a discussion of several religious and secular value systems that professionals can draw upon to inform and motivate moral action. 
than before. [It sets out] to dethrone the greed, violence, narrowness and lies that plague our existence.

What forms moral persons and builds ethical societies? Prozesky (2014: 295-298) argues that the home, beliefs and value-systems, the school, the workplace, the professions and leadership, sport, the universities and the political economy are means of moral inspiration and formation. Certainly, these are vital means by which personal and communal morality is shaped (or malformed - depending on the extent to which these conform to commonly accepted values). In a discussion of the need for human responsible effort in the service of the good, Prozesky (2007: 125) speaks of the importance of 'resolve' and 'moral backbone';

It means taking responsibility for things and not sitting back waiting for others to do something. It means strength of purpose and perseverance rather than half-heartedness, initiative rather than passivity, self-discipline and self-control, rather than weakness of will.

In short, human effort and resolve are required to form persons who are able to be moral and do what is right.

Notably, faith communities do not form part of this list (a point to which we return below). Interestingly, Prozesky (2014: 298-299) notes that ethics does not have 'its own dedicated organizational support' ... 'The result is that moral goodness is fragmented and dispersed, under-resourced and often voiceless. People of conscience, thinking about the grave moral ills all around them, can therefore be forgiven for feeling morally powerless and despondent'.

Christians accept Prozesky's stress on choice and conscience as important for the development of good character and conduct. From a Christian perspective, however, the extent of human moral capability to choose the good and the purity and reliability of human conscience and is not as great as Prozesky and others may imply. Thus, Biggar (2011: 37) states, 'Sin distorts moral cognition as well as moral motivation'. Therefore, moral education needs to overcome moral incapacity; to motivate and enable the formation of good character.

Human beings are capable of both moral altruism and evil. It is well known that some mothers go hungry so that their children can eat, and there are individuals and groups who are committed to fight for the survival of 
animals and the protection of the environment. Many social workers, pastors, psychologists and doctors spend time and energy to restore those who are hurt, broken and ill and some in government, business and civil society act in ways that are fair, honest and socially responsible. In contrast, millions of hideous acts of violence are perpetrated daily in our world. Some parents abuse their children, many animals are exploited, pollution poisons the environment and some social workers, pastors, psychologists and doctors are found guilty of grave malpractice. And, as already noted, some in government, business and civil society misuse their power in acts of theft, corruption, intimidation and the dereliction of duty. Moreover, can those who do not commit explicit acts of violence, honestly state that they never have evil thoughts, never wrestle with (or succumb to) temptation, never fail to assist others when it is in their power to do so, and never harm others in ways that stop short of physical violence? Can moral evil simply be triumphed over by good intentions and resolve?

Christians argue that because the world has 'fallen' into sin, human beings are in need of redemption. Unless the heart or inner self of a person is saved and transformed by God, moral choice cannot be properly exercised and formation fully fostered. This is based on Jesus's teaching in Mark 7: 20-23:

It is what comes out of a person that defiles. For it is from within, from the human heart, that evil intentions come: fornication, theft, murder, adultery, avarice, wickedness, deceit, licentiousness, envy, slander, pride, folly. All these evil things come from within, and they defile a person.

Thus, the goal is not self-improvement, but a radical renewal of character and life (see Colossians 3: 5-10). Christians believe that the training of conscience and the process of moral formation follow on from turning to God and being filled with the Holy Spirit; trust in God is both the foundation and motivation of the moral life.

Finally, Christian morality encompasses more than the knowledge of ethical values or critical ethical reflection; it is the pursuit of good character and a commitment to moral action in all spheres of life. Because we human beings often choose what is wrong, to the detriment of ourselves and others, our moral judgements and desires need to be redeemed. According to Biggar (2011: 80), 
... the moral life is primarily about the ordering of attitudes and dispositions, curbing some and growing others. Most fundamentally it is about the education of desire or love.

Furthermore, individual moral formation needs the support of a moral community, such as the family and Church, to transmit moral teaching and support moral development. For this reason, Kourie (2006: 88) notes that a secular spirituality, such as is proposed by Prozesky, once uprooted from 'established wisdom traditions', lacks 'community support', and has no adequate 'matrices for spiritual development' ${ }^{14}$. Indeed, as noted above, Prozesky himself laments the absence of 'dedicated organizational support' for ethics. Therefore, Wright (2010: 257 - 84) speaks of a Christian virtuous circle of moral formation that includes scripture, stories, examples, community and practices. The goal or purpose is for the virtues that are the 'fruit of the Spirit', namely 'love, joy, peace, patience, kindness, generosity, faithfulness, gentleness, and self-control' (Gal 5: 22 - 23b) to become rooted in the lives of Christians. Love for God and our wounded world, dedicated attention to the needs of others and a passion for social justice can be awakened, nurtured and given expression within such communities.

Hence, Christian ethicists agree that moral formation is a complex and multifaceted process, and that human beings have a vital role to play by being morally responsible and active. However, they would not agree with the views of scholars such as Prozesky that human persons on their own without God's work of redemption, motivation and empowerment, and the support of a committed moral community, are fully able to choose and follow a moral life or rescue humanity and the natural world from evil and decay.

\section{Conclusion}

The writings of Prozesky and other scholars, as discussed in this article, reveal a profound awareness of the ethical challenges facing societies across the globe. Biggar's approach of Barthian-Thomism creates space for a dialogue on morality and moral formation from a variety of standpoints. The various

${ }^{14}$ For a further discussion of the importance of moral community and faith practices see Koopman and Vosloo (2002: 8-9, 51-54, 98-127); Conradie 2006:47-55); and Hauerwas (1981 \& 1983). 
answers to Willard's four questions discussed above illustrate both convergence and divergence. A degree of convergence is seen in the answers to Willard's second question ('what is the good life'?) and third question ('who is truly a good person'?). Values such as justice and benevolence and virtues such as integrity and generosity are commonly accepted, but the divergence is seen in the varied understandings of the source and motivation of these values and the narrative that encompasses them.

With respect to Willard's first question ('what is reality?') and fourth question ('how does one become a truly good person?') a marked divergence can be detected. Whereas Biggar would see reality as being necessarily rooted in God, for scholars such as Prozesky this is not the case. Further, the perception of the ways in which good people are formed differs substantially among the scholars who have been quoted. Professor Prozesky is right to stress the importance of moral choice, conscience and commitment, and the need for an agreed understanding of ethics to bring about moral change in our global world. Thus far, substantial agreement can be reached on the basis of reason and Aquinas's natural theology. However, Christian ethicists have far less confidence in the moral capacity of human beings than do scholars such as Prozesky. The theological integrity that Biggar stresses means that insights drawn from the Christian scriptures, theology and experience have a crucial role to play in the discussion of human, social and environmental reality and the means of the moral development of individuals and communities. If this is God's world, a truly moral life cannot be lived apart from God.

\section{References}

Baker, W.R. 2009. A Reflection on Business Ethics: Implications for the United Nations Global Compact and Social Engagement and for Academic Research. (A commissioned paper for the UNESCO Forum on Higher Education, Research and Knowledge.) Available at: unesdoc.unesco.org/images/0018/001821/182184e.pdf. (Accessed on 31 August 2014.)

Beauchamp, T.L., L. Walters, J.P. Kahn \& A.C. Mastroianni 2014. Contemporary Issues in Bio-ethics. $8^{\text {th }}$ Edition. Stamford Conn: Wadsworth, Cengage Learning. 
A Christian Response to Prozesky's 'Global Ethic' and Secular Spirituality

Biggar, N. 1997. Good Life: Reflections on What we Value Today. London: SPCK.

Biggar, N. 2011. Behaving in Public: How to do Christian Ethics. Grand Rapids Mich: W.B. Eerdmans.

Business Ethics Network of Africa (BEN-Africa) 2018. Available at: http://www.benafrica.org/ (Accessed on 5 March 2018.)

Conradie, E.M. 2006. Morality as a Way of Life: A First Introduction to Ethical Theory. Stellenbosch: Sun Press.

Digital, T.M.G. 2016. Politics: Vytjie Mentor endorses Mcebisi Jonas over Proclamation on Guptas. Sunday Times: Times Live 16 March 2016.

Available at: https://www.timeslive.co.za/politics/2016-03-16-vytjiementor-endorses-mcebisi-jonas-over-proclamation-on-guptas/

(Accessed on 16 February 2018.)

Ethics Institute of South Africa. 2018. Available at: https://www.tei.org.za/

(Accessed on 5 March 2018.)

Gqubule, T. 2017. No Longer Whispering to Power: The Story of Thuli Madonsela. Johannesburg: Jonathan Ball.

Hauerwas, S. 1981. A Community of Character: Towards a Constructive Social Ethic. Notre Dame: University of Notre Dame Press.

Hauerwas, S. 1983. The Peaceable Kingdom: A Primer in Christian Ethics. Notre Dame: University of Notre Dame Press.

Haught, J.F. 2008. God and the New Atheism: A Critical Response to Dawkins, Harris, and Hitchens. London: Westminster John Knox Press.

Koopman, N.N. \& R. Vosloo 2002. Die Ligtheid van die Lig: Morele Oriëntasie in 'n Postmoderne Tyd. Wellington: Lux Verbi.

Kidder, R.M. 1994. Shared Values for a Troubled World: Conversations with Men and Women of Conscience. San Francisco: Jossey-Bass Publishers. Kourie, C.E.T. 2006. Postmodern Spirituality in Secular Society. In du Toit, C.W. \& C.P. Mason (eds.): Secular Spirituality as a Contextual Critique of Religion. Pretoria: Research Institute for Theology and Religion, Unisa. Kretzschmar, L. 2008. Christian Spirituality in Dialogue with Secular and African Spiritualities with Reference to Moral Formation and Agency. Theologia Viatorum 32, 1: 63-96.

Kretzschmar, L. 2012. Religious and Secular Moral Value Systems for Professionals in South Africa. In Kretzschmar, L., F. Prinsloo, M. Prozesky, D. Rossouw, K. Sander, J. Siebrits \& M.Woerman (eds.): Ethics for Accountants and Auditors. $3^{\text {rd }}$ Edition. Cape Town: Oxford University 
Press South Africa.

Kretzschmar, L. \& W. Bentley 2013. Applied Ethics and Tertiary Education in

South Africa: Teaching Business Ethics at the University of South Africa.

Verbum et Ecclesia 34,1. Art. \#804, 9 pages. DOI:

https://doi.org/10.4102/ve.v34i1.804

Küng, H. 1997. A Global Ethic for Global Politics and Economics. Bowden,

J. (trans.). London: SCM.

Kurtz, P. 1988. Forbidden Fruit: The Ethics of Humanism. Buffalo NY:

Prometheus Books.

Lowder, J.J. 2001. Summary of the Kurtz-Craig Debate. Available at:

https://infidels.org/library/modern/jeff_lowder/kurtz-craig.html

(Accessed on 16 October 2014.)

Mandela, N.R. 1994. Long Walk to Freedom: The Autobiography of Nelson Mandela. Boston: Little Brown.

Markham, I.S. 2007. Do Morals Matter? A Guide to Contemporary Religious Ethics. Oxford: Blackwell.

Nouwen, H. 1979. The Wounded Healer: Ministry in Contemporary Society.

New York: Image Books, Doubleday.

Pauw, J. 2017. The President's Keepers: Those Keeping Zuma in Power and

Out of Prison. Cape Town: Tafelberg.

Prozesky, M. 1984. Religion and Ultimate Well-Being: An Explanatory

Theory. London: The Macmillan Press.

Prozesky, M. (ed.) 1990. Christianity in South Africa. Bergvlei: Southern Book

Publishers. (Published by The Macmillan Press in London in 1990 under

the title, Christianity Amidst Apartheid.)

Prozesky, M. 1992. A New Guide to the Debate about God. London: SCM.

Prozesky, M. 1996. South Africa's Contribution to Religious Studies. In

Platvoet, J., J. Cox \& J.K. Olupona (eds.): The Study of Religion in Africa:

Past, Present and Prospects. Cambridge Eng: Roots and Branches.

Prozesky, M. 2006. Ethics, Spirituality and the Secular. In du Toit, C.W. (ed.):

Secular Spirituality as a Contextual Critique of Religion. Pretoria:

Research Institute for Theology and Religion, University of South

Africa.

Prozesky, M. 2007. Conscience: Ethical Intelligence for Global Well-Being.

Pietermaritzburg: University of KwaZulu-Natal Press.

Prozesky, M. 2009. Is the Secular State the Root of Our Moral Problems in

South Africa? Alternation Special Edition 3: 237-253. 
Prozesky, M. 2012. Studying Religion in South African Universities. In Venter, R. \& F. Tolmie (eds.): Transforming Theological Knowledge: Essays on Theology and the University after Apartheid. Bloemfontein: Sun Press. Prozesky, M. 2013. Corruption as the New Treason? Global Ethics, Africa's Moral Wisdom and the Corrupting of the Future. Ubuntu: Journal of Conflict Transformation: Special Issue: Corruption and Public Venality in Africa 2, 1 \& 2: 7-19.

Prozesky, M. 2014. Homo Ethicus: Understanding the Human Nature that

Underlies Human Rights and Human Rights Education. Journal for the Study of Religion 27, 1: 283-301.

Prozesky, M. 2016. Honest to God and the South African Churches in 2016.

Acta Theologica 36, 1: 152-169. DOI: http://dx.doi/10.4314/actat.v36i1.9

Rossouw, D. \& L. van Vuuren 2006. Business Ethics. $3^{\text {rd }}$ Edition. Oxford:

Oxford University Press.

Rossouw, D., M. Prozesky, M. Burger, C. du Plessis \& M. van Zyl 2007. Ethics

for Accountants and Auditors. Oxford: Oxford University Press.

Rossouw, D. \& L. van Vuuren. 2010. Business Ethics. $4^{\text {th }}$ Edition. Oxford:

Oxford University Press.

Venter, R. 2012. To Love God, the Poor and Learning: Towards an Ethic of Theological Knowledge. In Venter, R. \& F. Tolmie (eds.): Transforming Theological Knowledge: Essays on Theology and the University after Apartheid. Bloemfontein: Sun Press.

Willard, D. 1988. The Spirit of the Disciplines: Understanding how God Changes Lives. London: Hodder \& Stoughton.

Willard, D. 1998. The Divine Conspiracy: Rediscovering our Hidden Life in God. San Francisco: Harper.

Willard, D. 2009. Personal Religion, Public Reality: Towards a Knowledge of Faith. London: Hodder \& Stoughton. (Published in the USA, also in 2009, as Knowing Christ Today: Why we can Trust Spiritual Knowledge by Harper One.)

Wright, N. T. 2010. After you Believe: Why Christian Character Matters. New York: Harper One.

Young, E. 2010. Renowned Atheist-Turned-Deist Antony Flew Dies at 87. Available from: https://www.christianpost.com/news/renowned-atheistturned-deist-antony-flew-dies-at-87-44761/

(Accessed on 23 August 2014.) 
Louise Kretzschmar

Louise Kretzschmar

Theological Ethics

University of South Africa

kretzl@unisa.ac.za 